\title{
Towards operational payments for water ecosystem services in Tanzania: a case study from the Uluguru Mountains
}

\author{
Dosteus Lopa, Iddi Mwanyoka, George Jambiya, Thabit Massoud \\ Paul Harrison, Mark Ellis-Jones, Tom Blomley, Beria Leimona, Meinevan \\ NOORDWIJK and NEIL D. BURGESS
}

\begin{abstract}
Sustaining the regular flow of water from mountain forests is important for downstream stakeholders in seasonally dry tropical countries, and a watershed payment for ecosystem services (PES) scheme that links rural ecosystem service providers to urban water users through economic transfers may help to maintain water supply and forest habitat. A CARE/WWF project in the Uluguru Mountains of Tanzania has established a pilot watershed PES scheme. We trace the development of this scheme and outline its initial impacts. Memoranda of Understanding between companies in Dar es Salaam (the downstream water users) and farmers in the mountains provide the framework to deliver tangible financial benefits to local people, help change patterns of land use and potentially improve water quality. A number of lessons learned from this project are relevant for similar schemes elsewhere in the region. Overcoming the various challenges is essential for expanding the current pilot project to a scale where it delivers measurable changes in water quality for downstream users.
\end{abstract}

Keywords Africa, direct payments for conservation, Eastern Arc Mountains, payment for ecosystem services, PES, tropical forest, Tanzania, Uluguru Mountains

Dosteus Lopa and Thabit Massoud CARE International in Tanzania, Dar es Salaam, Tanzania

IdDi MWANYoKa WWF, Tanzania Country Offices, Dar es Salaam, Tanzania

GeORGE JAMBIYA Department of Geography, University of Dar es Salaam, Dar es Salaam, Tanzania, and WWF, Tanzania Country Offices, Dar es Salaam, Tanzania

PaUl Harrison Kilimanyika Limited, Bicester, UK

MARK ELLIS-JONES Naivasha, Kenya

Tom Blomley Acacia Natural Resource Consultants Ltd, Reading, UK

Beria Leimona and Meine van Noordwijk ICRAF, Nairobi, Kenya

NeIL D. BuRgess (Corresponding author) Centre for Macroecology, Evolution and Climate-Department of Biology, University of Copenhagen, Denmark, Conservation Science Program, WWF, Washington, DC, USA, and Valuing the Arc Programme, Department of Zoology, University of Cambridge, Downing Street, Cambridge, CB2 3EJ, UK. E-mail ndburgess@bio.ku.dk

Received 13 February 2011. Revision requested 5 May 2011.

Accepted 6 July 2011.

\section{Introduction}

$\mathrm{T}_{\mathrm{t}}$ is widely recognized that natural ecosystems produce 1 a broad range of environmental services (Daily, 1997; Balmford et al., 2002; MEA, 2005), including carbon sequestration by forests, regulation of water quantity and quality, scenic beauty and biodiversity. The failure of society to compensate land managers for the provision of these services is regarded as a key factor contributing to rapid changes in land use, in particular the global degradation of ecosystems (Butchart et al., 2010).

Payments for ecosystem services (PES) has been proposed as one way to deliver better conservation by financially linking beneficiaries of an ecological service back to the people who manage the resource that provides the service (Ferraro, 2001; Ferraro \& Kiss, 2002; Wunder, 2007, 2008; Pagiola, 2008; Wunder et al., 2008; Clements et al., 2010; Pattanayak et al., 2010). PES schemes have been defined as a voluntary transaction in which a well-defined ecosystem service (or corresponding land use) is 'bought' by a minimum of one ecosystem service buyer from a minimum of one ecosystem service provider if, and only if, ecosystem service provision is secured (conditionality). As it is often hard to provide reliable measures for ecosystem services, proxies based on changes in land use or management are often used. Failure to fulfil all criteria results in some approaches being termed PES-like schemes (Wunder, 2005a,b). Existing PES schemes include those where payments are made for ecological tourism (Clements et al., 2010), water provision (Dudley \& Stolton, 2003; Asquith et al., 2008; Muñoz-Piña et al., 2008; Pagiola, 2008; Wunder \& Albán, 2008), forest carbon (REDD+ mechanisms; Burgess et al., 2010a; Clements, 2010), pollination of crops (Ricketts, 2004) and delivery of biodiversity outcomes (Clements et al., 2010; Sommerville et al., 2010; Gross-Camp et al., 2011).

PES schemes, by definition, use the direct payments approach of cash payments to individuals, as advocated by Ferraro \& Kiss (2002). Research suggests that, when compared with indirect conservation approaches, direct payments within PES schemes are (1) institutionally simpler, (2) more cost-effective in delivering benefits to buyers, (3) more effective in generating economic growth among suppliers by improving cash flow, diversifying income 
sources, and reducing income variance, and (4) provide new sources of finance for conservation (Ferraro, 2001; Ferraro \& Kiss, 2002; Pattanayak et al., 2010). However, some have argued that direct payments are also institutionally complex to implement in poor communities with insecure land tenure and weak institutions, and favour other, non-PES, approaches to providing collective benefits, such as schools and health clinics (Leimona et al., 2009; Milne \& Niesten, 2009). Evidence for the impact of both approaches is limited.

Market-based implementation of PES schemes is occurring in parts of Latin America and South-East Asia (Pattanayak et al., 2010), with somewhat mixed results. In Africa most PES schemes are in the pilot stage and heavily supported by donors and NGOs, are not yet self sustaining financially or technically (Ferraro, 2009), and lack adequate monitoring mechanisms to ensure compliance. PES schemes in Africa that lack conditionality and monitoring mechanisms to ensure the ecosystem service is delivered are operationally similar to integrated conservation and development projects whose initial popularity ended when expensive pilot projects were shown to deliver few conservation or livelihoods benefits, and sustainability proved elusive (Ferraro \& Kiss, 2002; McShane \& Wells, 2004; Burgess et al., 2010b; Clements et al., 2010).

We present a case study of a pilot water PES project in the Uluguru Mountains of Tanzania (Fig. 1a) and trace its development, operationalization, outline the payment mechanism, and discuss the likelihood of it achieving sustainability. We also use a proposed PES and poverty alleviation framework (Wunder, 2008) to explore the extent that poor people are able to participate in this PES scheme as buyers or sellers of environmental services. The lessons learned from this project are relevant to promoting the emerging market-based conservation approach more broadly in tropical Africa.

\section{Study area}

The Eastern Arc Mountains are in eastern Africa, mostly in Tanzania (Fig. 1a). The summits of these steep mountains are tropical cloud forest, lying within a network of reserves (Hall et al., 2009) that support globally important biodiversity with many endemic and threatened species (Burgess et al., 2007). Hydrologically these mountains are of critical importance. Water flows from the forests throughout the year and provides services to millions of people, including c. $60 \%$ of Tanzania's electricity generation, and drinking water for at least $20 \%$ of the human population, $>80 \%$ of Tanzanian industry, and much of the irrigated agriculture (Ministry of Finance and Economic Affairs, 2008; Fisher et al., 2010, 2011). Most of the benefits from this water are realized far from the catchment forests where the water originates.

The Uluguru Mountains (200-2,638 m altitude) form the major catchment to the Ruvu River and are c. $200 \mathrm{~km}$ inland (Fig. 1b). Total annual rainfall is 1,000-3,000 mm. As altitude increases the vegetation changes from miombo woodlands and coastal and transitional rainforests to submontane, montane and upper montane forests. The area includes an area of Afromontane grasslands on the Lukwangule Plateau. The submontane to upper montane forests and grasslands lie within the 72,000-ha Uluguru Nature Reserve (Fig. 1b). These habitats are rich in endemic species and of high conservation priority (Burgess et al., 2002, 2007). Over 150,000 people live within the mountain area and human density is greater at higher altitudes, with farmland up to the Nature Reserve boundary.

CARE International and WWF Tanzania have been implementing the Equitable Payments for Watershed Services (EPWS) project since 2005. This project emphasizes the fair and equitable distribution of benefits accruing from the sale of ecosystem services to downstream users, and is centred on the Kibungo sub-catchment in the southeastern Uluguru Mountains (Fig. 1c; Branca et al., 2009). Funding to establish the mechanism has been provided by the Danish and Dutch Governments, totalling c. EUR 1.3 million.

The first phase of the EPWS (2005-2007) comprised a feasibility assessment, a series of consultancies to establish the baseline, the formulation of an outline business case, and the signing of memoranda of understanding with potential service buyers. The second phase (2008-2012) has established water PES on a pilot scale, engaging four communities and two downstream water users. A proposed third phase, where local stakeholders own the project after the exit of foreign donors (Directorate General for International Cooperation (DGIS) of the Netherlands, Danish International Development Agency (DANIDA)) and managers (CARE International, WWF), will emphasize sustainability and scale up the programme to include 50-75 communities across the Uluguru Mountains. Phase three is contingent upon long-term legally binding contracts being signed between buyers and sellers and the development of a full business case and strategy for programme expansion to new sub-catchments.

\section{Environmental challenges in the Uluguru Mountains}

The Uluguru Mountains receive rainfall every month and this supports year-round crop production. However, decades of inappropriate land use have resulted in erosion and nutrient exhaustion of the soils and led to declines in crop productivity (Lyamuya et al., 1994; Hartley \& Kaare, 2001; Branca et al., 2009; Harrison et al., 2010). Large areas of 

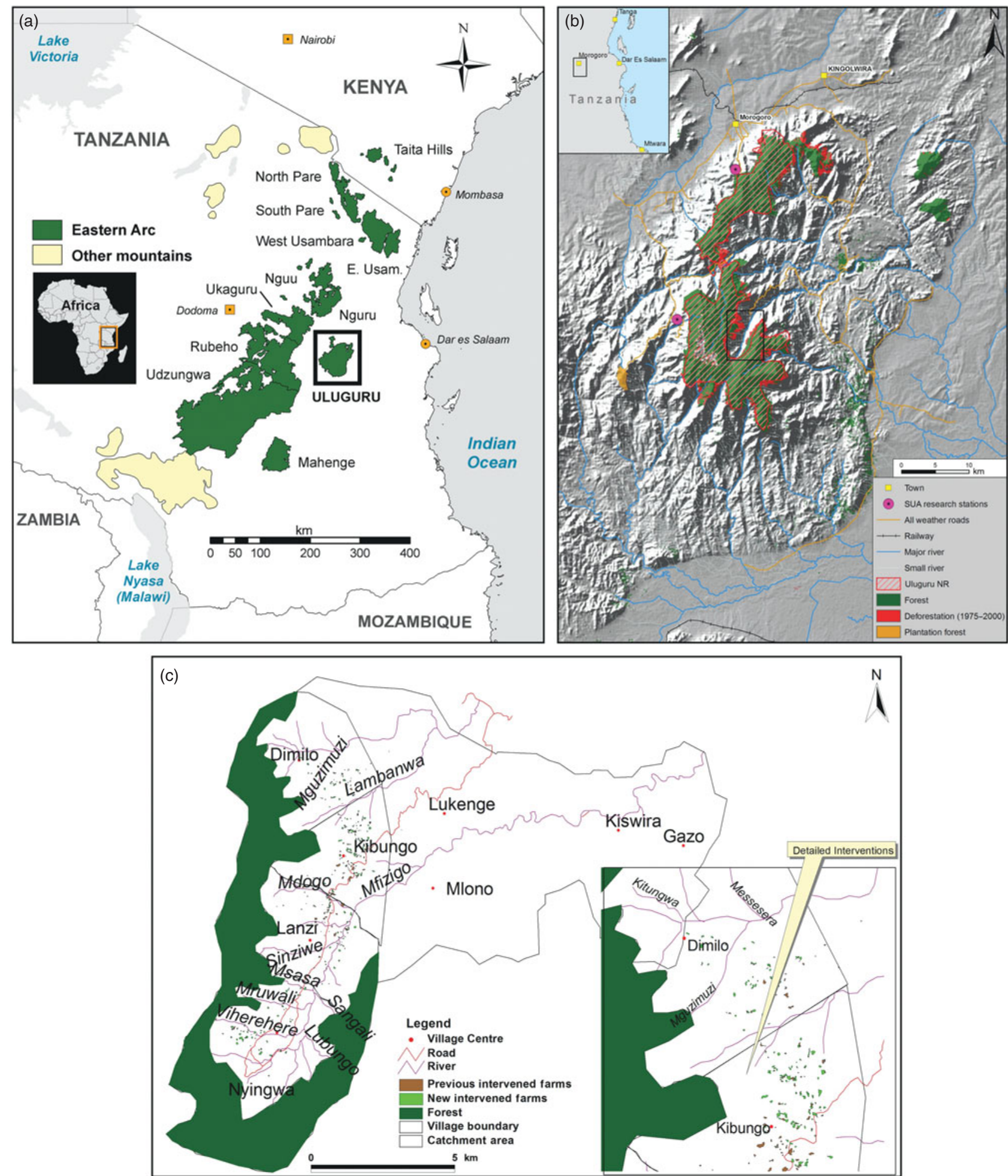

FIG. 1 (a) Tanzania and the Eastern Arc Mountain range (the rectangle indicates the Uluguru Mountains; modified from Platts et al., 2011), with the location of the main map in East Africa indicated by the rectangle on the inset. (b) The Uluguru Mountains showing the location of the PES pilot scheme within the rectangle, forest cover in 2000, the boundaries of the Uluguru Nature Reserve (NR), and the main rivers and streams. (c) Kibungu sub-catchment in the Uluguru Mountains, showing the location of villages and small streams and the location of the focal villages and individual farmers' fields under project interventions (inset).

bracken fern Pteridium aquilinum growing in the farmlands of the study area indicate the poor nutrient status of the soil (Nsenga, 2009). Social surveys of 83 households in 2007 show that $89.2 \%$ of villagers are subsistence farmers with no more than 1 ha of land, low levels of education (66.7\% with only primary education), living in mud houses with thatch 
(a)

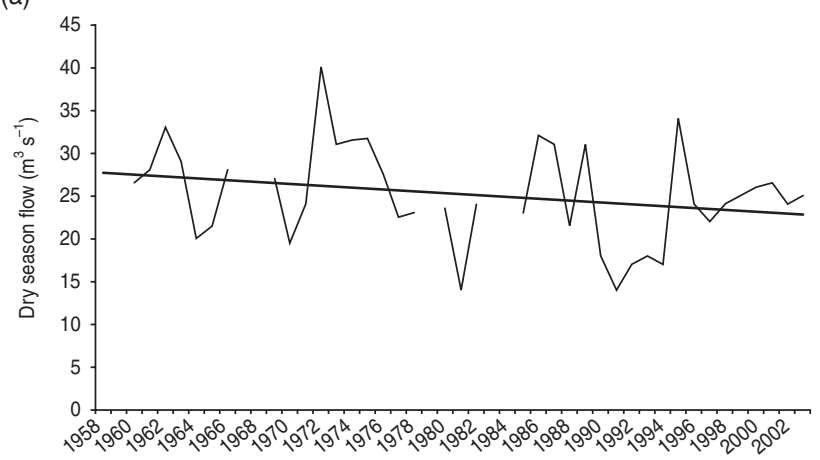

(c)

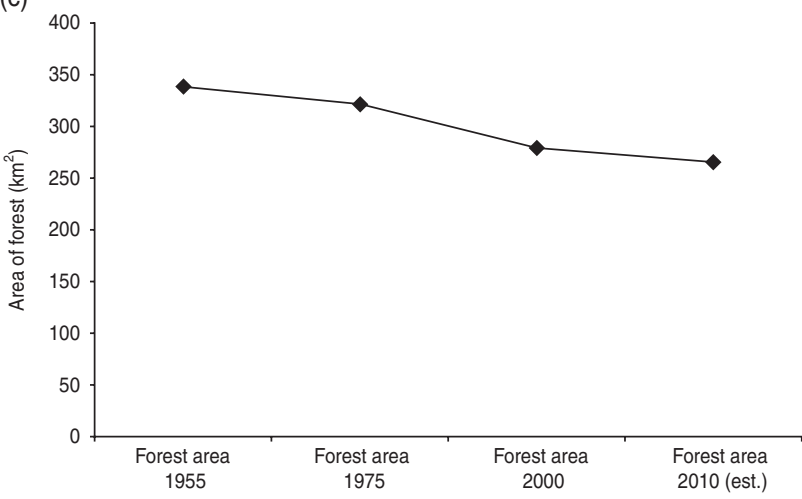

(b)

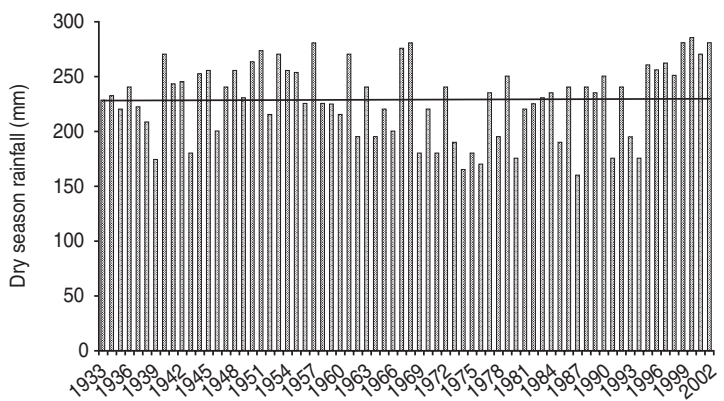

(d)

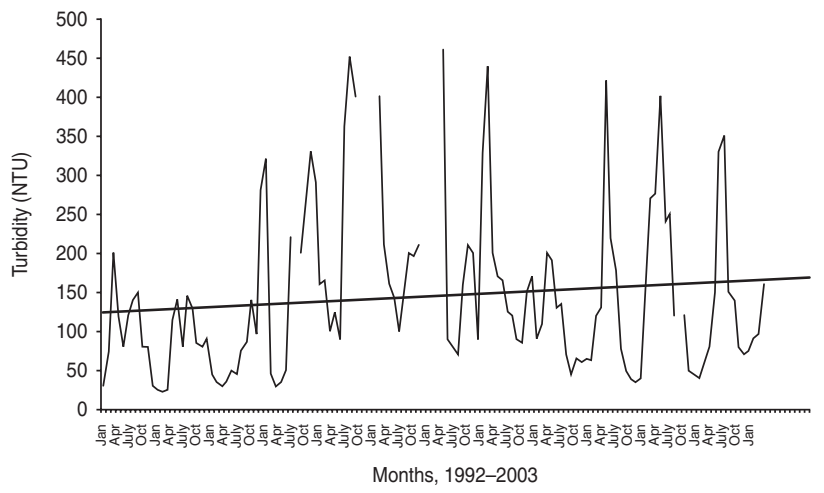

FIG. 2 Trends in (a) dry season water flow for 1958-2003 (from the water intake at the Morogoro Road bridge across the Ruvu River mid way between the Uluguru Mountains and Dar es Salaam; regression line: $\left.y=-0.109 x+27.838 ; R^{2}=0.064\right)$, (b) dry season rainfall (mean of three stations) in Ruvu Basin for $1933-2003\left(y=0.0236 x+227.73 ; R^{2}=0.002\right)$, (c) forest cover in the Uluguru Mountains in 1955, 1975, 2000 and estimated for 2010, and (d) monthly turbidity for 1992-2003 (from the water intake at the Morogoro Road bridge) in the Uluguru Mountains and Ruvu River system (regression line: $y=0.312 x+123.44 ; R^{2}=0.014$ ).

roofs, and with almost no land title deeds (CARE/WWF, 2007). Cash income levels are unknown but are certainly low (Harltey \& Kaare, 2001; CARE/WWF, 2007; CARE \& WWF, unpubl. data). A pre-requisite for site selection was the livelihood status of farming communities, as they had to be at, or below, the poverty line.

A marked decline in dry season water flow over the past 53 years has been recorded on the Ruvu River at the offtake for the Dar es Salaam water supply (Fig. 2a). Over a similar time period (1933-2004) there is no appreciable change in dry season rainfall (Fig. 2b). However, analysis of forest cover in the Uluguru range (Mbilinyi et al., 2006; Hall et al., 2009) suggests that the decrease in water flow is probably a result of forest reduction (from 338 to $279 \mathrm{~km}^{2}$ during 1955-2000; Fig. 2c), combined with increased offtake for agriculture and urban use. Forest reduction has been driven by the expansion of agricultural areas into the forest land, and degradation of the forest from cutting of timber for building poles and firewood (Frontier-Tanzania, 2005; Madoffe \& Munishi, 2005, 2010; Mbilinyi et al., 2006). Despite a lack of firm evidence, land-use changes have probably affected the hydrological regime in the Ruvu Basin, and human population growth and greater use of irrigation will have increased water use (Mtalo, 2005; Yanda \& Munishi, 2007).

Data on water turbidity in the Ruvu River at the extraction point for Dar es Salaam's water supply shows an increase over a 10-year period (Fig. 2d). Between 1992 and 2003 turbidity increased at an average of 5 nephelometric turbidity units (NTU, a measure of the suspended material in water) per year, with turbidity values of 100-200 NTU towards the end of the decade. The standard for drinking water is normally set at one NTU, with water of 10 NTU interfering with, or damaging, treatment filters, which can result in intake closures at drinking-water facilities. As a consequence, the Dar es Salaam Water and Sewerage Cooperative (DAWASCO) is experiencing year-on-year increases in water treatment costs.

To address these issues the Tanzanian government has developed the policy foundation for watershed PES in Tanzania, partly building on earlier consultancy studies (Kulindwa, 2005; Mwanyoka, 2005; Kulindwa et al., 2006). The Water Resources Management Act (2009), paragraph 96 (p. 406) states that 'Water Basin Boards may announce charges with respect of "payments for environmental services"'. Instruments for economic incentives are also 
found in the Environmental Management Act Cap 191 of 2009. The policy has yet to be implemented on any meaningful scale and this article is the first to explore the potential of such interventions.

\section{Methods}

The team writing this article comprises the project managers (the first two authors), consultants who have advised or appraised the project (the next set of authors), and a semi-independent academic who has worked in the Ulugurus for many years but who has not been directly involved in implementing this project (last author). The team reviewed all project documentation, various consultant reports, background information on the site and other water PES projects in Africa and globally, and visited the field site on several occasions. As this project has been established within the previous 5 years the monitoring systems to measure outcomes for people and the environment have only been operational for a few years, and hence attributing changes to the project's activities has proven difficult. However, as this is a key deliverable for the pilot project, we discuss it further later.

Given the specific focus of the EPWS on achieving equitable outcomes, we used a framework (Wunder, 2008) to evaluate the potential of this programme to reduce rural poverty:

- Participation filters: to what extent do poor people participate in PES schemes as buyers and sellers of environmental services?

- Effects on sellers: if the poor become service sellers does this have any positive effect on their income?

- Effects on users: do poor service buyers (and nonpaying poor service users) become better off from their involvement in PES?
- Derived effects: how are other, non-participant poor affected by PES outcomes?

We also evaluated the degree to which non-income benefits have been produced through engagement in the PES scheme.

\section{Results}

\section{Programme progress and impacts}

An initial set of baseline studies assessed hydrological and land uses (Yanda \& Munishi, 2007), livelihoods (CARE/ WWF, 2007) and erosion hotspots within the landscape (Gathenya, 2009). The project also mapped land use and ownership and characteristics of farm plots in the project area. Monitoring water flow and quality began in March 2010 with the installation of two stations to measure river flow and one automatic weather station, and more detail on livelihoods impacts are being assessed in 2011.

The EPWS programme comprises a project unit in Morogoro and an intermediary group composed of influential government officers in Dar es Salaam. Together, they have prepared business cases for companies in Dar es Salaam, negotiated memoranda of understanding with two major water users in the city, and developed the mechanism for disbursing funds. The two water users are the Dar es Salaam Water Company (DAWASCO) that currently spends nearly USD 2 million per year on water treatment, and Coca Cola Kwanza Limited (CCKL) that is dependent on DAWASCO for approximately $1,500 \mathrm{~m}^{3}$ of water per day.

At the operational level the EPWS structure (Fig. 3) comprises an agreement between CARE Tanzania and four village authorities (Kibungo, Nyingwa, Lanzi and Dimilo; total population 4,860 ) where CARE is the intermediary

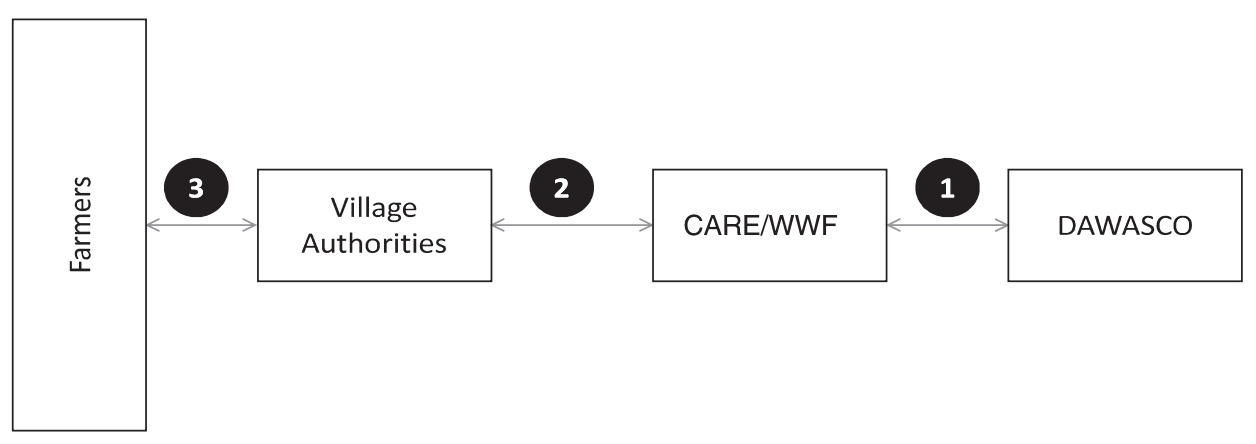

(1) Agreement under which DAWASCO agrees to pay CARE for the purpose of PES

2 PES contract setting out the conditions under which payment will be given

(3) Village authorities pass payments to individuals who meet the conditions of the FIG. 3 EPWS transaction structure linking sellers to PES contract buyers via CARE/WWF. 
TABLE 1 Number of farmers implementing sustainable land-use practices by May 2010 in the four focal villages (Fig. 1).

\begin{tabular}{|c|c|c|c|c|c|c|}
\hline \multirow[b]{2}{*}{ Village } & \multirow[b]{2}{*}{ Population } & \multirow[b]{2}{*}{ Type of intervention* } & \multirow{2}{*}{$\begin{array}{l}\text { No. of terraces/ } \\
\text { trees planted }\end{array}$} & \multicolumn{3}{|c|}{ No. of participating farmers } \\
\hline & & & & Male & Female & Total \\
\hline \multirow[t]{2}{*}{ Kibungo } & \multirow[t]{2}{*}{1,116} & Terraces & 261 & 24 & 16 & 40 \\
\hline & & Tree planting & 35,000 & 56 & 52 & 108 \\
\hline \multirow[t]{2}{*}{ Nyingwa } & \multirow[t]{2}{*}{1,734} & Terraces & 209 & 48 & 9 & 57 \\
\hline & & Tree planting & 19,000 & 113 & 44 & 157 \\
\hline \multirow[t]{2}{*}{ Dimilo } & \multirow[t]{2}{*}{909} & Terraces & 164 & 22 & 7 & 29 \\
\hline & & Tree planting & 22,000 & 42 & 26 & 68 \\
\hline \multirow[t]{2}{*}{ Lanzi } & \multirow[t]{2}{*}{1,101} & Terraces & 165 & 18 & 15 & 33 \\
\hline & & Tree planting & 30,000 & 30 & 22 & 52 \\
\hline \multirow[t]{3}{*}{ Total } & \multirow[t]{3}{*}{4,860} & Terraces & 799 & 112 & 47 & 159 \\
\hline & & Tree planting & 106,000 & 241 & 144 & 385 \\
\hline & & & & 353 & 191 & 544 \\
\hline
\end{tabular}

*Terraces: bench terraces, fanya juu and fanya chini; tree planting: agroforestry and reforestation

agent of DAWASCO. Village authorities agree to implement and maintain a set of specified soil conservation measures and to pass payments from CARE to participating farmers. In return, CARE agrees to make payments on behalf of DAWASCO according to the work done by farmers. Additionally, CARE provides materials to implement soil conservation measures and makes an annual payment of USD 1.50 for each acre (USD 0.6 per ha) of land under improved land-use practice. These funds are used to purchase materials to facilitate communication, namely stationery and mobile phone credit. Contract negotiations were undertaken at well-publicized public meetings in all villages in October 2008. Compliance is ensured through signed agreements between village authorities and CARE and regular village meetings. Records on numbers of farmers, types of measures, land areas and payment records are maintained both in the village and by the project.

The number of farmers participating in the project increased 3.5 fold within 1 year of the project's inception in July 2009 (from 144 to 544 participants), perhaps because of the financial incentives. Adoption of improved agricultural practices was initially supported by the project, and later by financial payments via the PES mechanism (Table 1). Interventions include agro-forestry, reforestation, grass strip planting and terrace development. Agroforestry intervention targeted restoration activities in the erosion hotspots, which involved planting fruit and timber trees (e.g. the exotic mango Mangifera indica, oranges Citrus sinensis, avocado Persea americana, Leucaena leucocephala, Casuarina spp. and Grevillea robusta) and the native Faidherbia albida, Khaya anthotheca (timber) and Allanblackia stuhlmannii (oil bearing fruit). However, adoption of agroforestry and other interventions is dependent on the willingness of farmers to participate and this has resulted in a patchwork of intervention sites (Fig. 1c). According to discussions with farmers and from
TABLE 2 Total area of the various interventions undertaken by the EPWS project.

\begin{tabular}{ll}
\hline Intervention type & Total area, acres (ha) \\
\hline Bench terrace & $70(28.3)$ \\
Reforestation & $33(13.3)$ \\
Agroforestry & $47(19.0)$ \\
Grass strip & $50(20.2)$ \\
Fanya juu fanya chini & $32(12.9)$ \\
Riparian restoration & $40(16.2)$ \\
\hline
\end{tabular}

the project team's knowledge, farmers adopt the practices primarily because they receive agricultural extension advice that is not available any other way and because they receive payments. Terrace development includes the local terrace types fanya juu (soil from trench on upper edge) and fanya chini (soil from the trench on lower edge). These two approaches are used to develop more standard bench terraces. These intervention areas are scattered across the project villages (Fig. 1c) and occupy relatively small parcels of land (Table 2).

Using funding provided by DAWASCO the project paid TZS 2.1 million (USD 1,640) in May 2010 to the initial 144 participants (Fig. 4) that had made improvements to their land management practices in 2009. Payments were made to individual farmers based on the area of different land improvement technologies applied, the labour costs and loss of income in the short term (Table 3). Opportunity costs of the land-use practices were evaluated by CARE/WWF upon consultation with discussion groups and village assemblies, and evaluation of economic returns provided by maize, beans, cassava, rice and banana, the most common crops in the Uluguru area. Each farmer received USD $8-48$ according to the area of land converted to the improved farming technologies. All payments were made after verifying that the work had been done. Verification was achieved by visiting the field to see which 


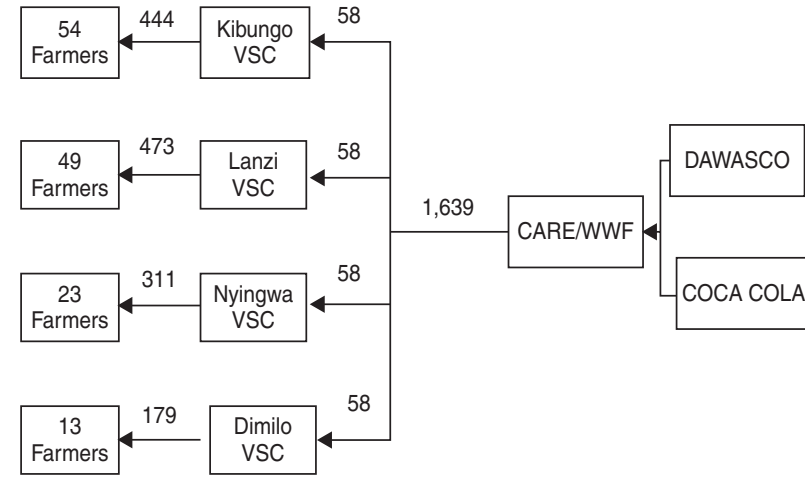

FIG. 4 Model of the distribution of funds provided by DAWASCO to 144 farmers who had completed land improvement work in 2009 in the Kibungo sub-catchment, via four Village Security Committees (VSC; Harrison et al., 2010). Numbers above arrow lines are USD.

type of technology was being implemented and measuring the area of the land with a global positioning system, with data transferred into a geographical information system. This occurs every time the project team visits the farmers in their fields. At this pilot project stage the funding from DAWASCO is in the form of corporate social responsibility; the money is provided as a grant and the company is not expecting a real change in water quality. This would only be realized if the project is scaled up and payments are contingent upon improved water quality being delivered downstream.

\section{Benefits to forests and biodiversity}

The baselines of forest cover (Mbilinyi et al., 2006; Hall et al., 2009) and forest disturbance (Madoffe \& Munishi, 2005) were updated in 2010 from field surveys, to assess disturbance (Madoffe \& Munishi, 2010), and analysis of 2007/2008 Landsat 7 images (Mbilinyi \& Kashaigili, 2010). No changes in rates of disturbance can be demonstrated over this time period but from 2000 to 2008 forest on the Uluguru Mountains declined from 279 to $263 \mathrm{~km}^{2}$ (5.5\%), mainly in unprotected forest lands to the north of Uluguru Nature Reserve.

\section{Changes in rural livelihoods}

Farmers participating in the scheme received financial payments to compensate for their labour and opportunity costs (reduction in crop production; Table 3 ), and have used the additional money to purchase iron sheet roofing for their houses, goats for milk and manure production, and better clothes and to pay school fees. Baseline income levels in the project area were too low to make these investments (Hartley \& Kaare, 2001; CARE/WWF, 2007). Farmers have also used the money they have received to purchase extra agricultural inputs, namely better seeds to improve agricultural yields. In September 201025 farmers purchased cabbage seeds using PES funding, which allowed them to change some of their land to a new crop with higher economic value (Table 4), multiplying the livelihood impacts of the PES payments.

\section{Potential to reduce rural poverty}

Participation filters Poor people in the Uluguru Mountains have been helped to move towards selling environmental services to downstream water users. Farmers, through CARE, have sold DAWASCO the promise of improved water quality from altered farming practices, for which they have benefited financially. Most participating farmers are middle income according to local norms. Participation by poorer households may have been limited because they have less available land with which to experiment and tend to focus on core food crops for subsistence. Exclusion of the poorest people has been observed elsewhere in similar schemes (Pascual et al., 2009).

Effects on sellers In July 2009144 farmers had joined the scheme and were paid in May 2010 the equivalent of a total of USD 1,639 as an annual payment to compensate for their efforts to improve land management, reduce erosion and improve water quality. By May 2010554 local farmers had become sellers in the scheme, increasing to 650 by November 2010. In July 2011 participating farmers were paid a total of USD 11,00o for their efforts to improve land. As new people are still joining the scheme the expected payment in 2012 will be higher. This pilot project is therefore moving towards becoming an operational PES scheme. The EPWS scheme expects farmers to use payments for agricultural production and investment, and is providing extension support to assist with this. An example is the initiation of commercial agriculture (e.g. cabbages), which provides a greater improvement of livelihoods than is possible without the PES payments.

Effects on users The only paying buyer so far is the main water utility company in Dar es Salaam. It hopes that its initial investment in the scheme will help improve water quality and hence reduce water cleaning costs and that the savings can be passed on as increased profits and reduced water tariffs. Lower water tariffs would mainly be beneficial to the richer households in Dar es Salaam that access mains water, and industry. Poor people rely on informal collection by bucket of water from standpipes, from boreholes, or by accessing water pipes without making payments. As such the benefits to poor urban residents of this scheme, or even a similar one that is considerably scaled up, are likely to be marginal. 
TABLE 3 Approach used to calculate amounts paid to farmers according to the technologies employed to reduce erosion and improve yields (original prices in TZS converted to USD at $1,250 \mathrm{TZS}={ }_{1} \mathrm{USD}$ ).

\begin{tabular}{|c|c|c|c|c|c|}
\hline Technology & $\begin{array}{l}\text { Land removed } \\
\text { from productive } \\
\text { use in 1st year (\%) }\end{array}$ & $\begin{array}{l}\text { Loss associated with } \\
\text { removing land from } \\
\text { productive use } \\
\left(\mathrm{USD} \mathrm{ha}^{-1}\right)\end{array}$ & $\begin{array}{l}\text { Labour } \\
\left.\left(\text { days }^{-1}\right)^{-1}\right)\end{array}$ & $\begin{array}{l}\text { Labour cost } \\
\left(\mathrm{USD} \mathrm{ha}^{-1}\right)\end{array}$ & $\begin{array}{l}\text { Total cost } \\
\left(\mathrm{USD} \mathrm{ha}^{-1}\right)\end{array}$ \\
\hline Bench terrace & 100 & 128 & 140 & 168 & 296 \\
\hline Fanya juu & 20 & 26 & 104 & 124 & 151 \\
\hline Reforestation & 100 & 128 & 50 & 60 & 188 \\
\hline Agroforestry & 17 & 22 & 9 & 11 & 33 \\
\hline
\end{tabular}

${ }^{1}$ Opportunity cost was calculated in consultation with community members and relates to agricultural income for main crops linked to area removed from production for each technology. This was agreed to be TZS 160,000 (USD 128) per ha.

${ }^{2}$ Communities were consulted to obtain the local labour day market price, which was TZS 1,500 (USD 1.2). This was then multiplied by number of labour days required for respective action.

TABLE 4 Example use of PES funding: improved cabbage production in November 2010.

\begin{tabular}{lcccc}
\hline Village & $\begin{array}{l}\text { No. of } \\
\text { farmers }\end{array}$ & $\begin{array}{l}\text { No. of } \\
\text { cabbages }\end{array}$ & $\begin{array}{l}\text { Mean } \\
\text { no. of } \\
\text { acres }\end{array}$ & $\begin{array}{l}\text { Approximate } \\
\text { value (USD) }\end{array}$ \\
\hline Kibungo & 7 & 3,855 & 4 & 1,349 \\
Dimilo & 4 & 2,143 & 4 & 750 \\
Lanzi & 3 & 2,214 & 2 & 775 \\
Nyingwa & 11 & 11,860 & 6 & 4,151 \\
Total & 25 & 20,072 & 16 & 7,025 \\
\hline
\end{tabular}

Derived effects In the pilot area c. $25 \%$ of the farmers are participating in the scheme and only a small part of the available land is under improved management. Farmers who are not part of the scheme have started to copy land interventions, suggesting they are willing to experiment but wish to avoid the formal structures of the scheme. The reasons for their decision have yet to be determined. More broadly across the Ruvu Basin and in the downstream city of Dar es Salaam the vast majority of non-participating people and industrial users of water are unaffected by not being involved in the scheme; as such its impact is limited.

Non-income benefits The creation of farmer's groups by the project has led to greater interactions and potential for learning. Other benefits are the introduction of novel farming technologies such as stall-fed goats and sheep, allowing the collection and application of manure that is expected to increase crop yields. However, none of these interventions are directly attributable to the scheme or derived from the limited payments that have been made to communities using funds made available by DAWASCO.

\section{Discussion}

We have outlined a pilot project in the Uluguru Mountains that is seeking to develop an operational PES scheme. Some of the initial results may eventually result in improved water quality for downstream users and forest conservation and improved livelihoods in the Mountains. This pilot scheme started at a small scale and has developed according to the demand of local farmers, using project and corporate social responsibility funds. Contracts are in place with several hundred farmers. The work has built upon previous agricultural work by CARE in these Mountains, and a collaboration with a local NGO (Ulguru Mountains Agricultural Development Project) that has been working with farmers in these Mountains for many years. The project's plan is to extend the scheme within the watershed and seek to deliver greater benefits, similar to the approach used in Los Negros in Bolivia (Asquith et al., 2008).

This pilot project is of interest because there are few operational water PES schemes in Africa compared to other tropical regions (Ferraro, 2009). One reason is a lack of willing buyers who have funding to invest in these schemes (typically hydroelectric power suppliers, large industrial users, municipal water suppliers, irrigation water users and general tax revenues). Additionally, the high levels of poverty in the rural and urban populations of Africa make it harder to institute formal payment systems for the general public. Other constraints include high transaction costs, weakly formalized land tenure and insufficient enabling policy and legal frameworks, fewer supporting institutions, and a general lack of capacity in relevant disciplines (Ferraro, 2009). Together these make the establishment of PES schemes in Africa more challenging than elsewhere. These challenges are all present in the Uluguru Mountains.

Engel et al. (2008) and Wunder et al. (2008) suggested that the supply of environmental services from a PES project depends on four related issues: enrolment, conditionality, additionality and land use-service linkages. Within the EPWS project in the Uluguru Mountains the number of farmers wishing to join the scheme increased rapidly and continues to increase, mainly because farmers noted the increasing crop production of those who joined the scheme and because there was a financial incentive. This finding is similar to studies of pilot projects elsewhere (Pattanayak et al., 2010). 
In terms of conditionality the EPWS project pays farmers on the delivery of a land-use improvement technology that is expected to reduce run-off and hence improve water quality (van Noordwijk \& Leimona, 2010). This is despite the fact that a direct link between land-use changes and water quality improvement has not yet been established and that conditionality does not really exist in the payments, which will be a problem for scaling the pilot project into a full PES scheme. Currently, payments are related to the labour costs of undertaking the activities or are compensating opportunity lost (van Noordwijk \& Leimona, 2010). It has been proposed that the payment is annual and part of the full PES scheme but the reality is that its continuation depends on the provision of grant funds from DAWASCO or Coca Cola, government donors, or NGOs. Making payments fully conditional on delivery of improvements in services, and finding a sustainable source of funding, is vital to ensure that farmers maintain the implemented changes instead of reverting to old practices.

With respect to additionality, some changes in land use, namely bench terraces, would not have occurred without the project's presence. This is because bench terracing has a politically charged history on the Ulugurus (Young \& Fosbrooke, 1960), having been forcibly imposed by the British colonial authorities and forcibly rejected by the local people. It is less certain whether other land-use changes can be attributed to specific payments from water users, or whether adoption is driven by other benefits, such as improved agricultural practices, increased yields and increased social capital and capacity through the formation of farmer groups. Furthermore, given the relatively small area of land covered by improved land management practices it is not yet possible to detect any significant change in water quality indicators downstream, and it is not known how large the intervention area will need to be to demonstrate real impact. As farmer numbers increase, it will be critical to track these changes to be able to link land-use change to water service change, particularly if additional buyers are to be engaged.

Until now the institutional framework for the Uluguru PES scheme has been provided by NGOs, with funding from two European development assistance agencies and with the political blessing of the government and the Water Basin Authority. Costs of the project interventions are high compared with the benefits that have been delivered, as with earlier integrated conservation and development projects in this area (Burgess et al., 2010b). It can, however, be argued that these high start-up costs are inevitable in a country with no past history of water PES schemes, and that future efforts, or expansion of the existing effort, will be cheaper and have a chance to be sustainable. This was not the case with the integrated conservation and development projects.

In terms of the Uluguru PES payment arrangements, all negotiations with buyers have been carried out by
CARE/WWF because communities lacked capacity to undertake the negotiations. A switch over to community negotiation will be important for ensuing long-term sustainability and developing a mechanism that can be replicated at a larger scale across the Uluguru Mountains. A self-sustaining method for receiving funds and making payments is also required beyond the current project lifespan. Options include the Eastern Arc Mountains Conservation Endowment Fund (EAMCEF, 2011), or the semi-autonomous Water Basin Boards. In the future payments could also be sent direct from buyers to sellers using text message mobile phone banking technology, which already exists, cutting out middlemen, simplifying the procedure and dramatically reducing transaction costs.

Monitoring compliance is currently the task of the NGOs that are providing the funding, which is perhaps appropriate in these initial stages but is not ideal in the longer term. In other community-based schemes the basic monitoring is being undertaken by the local communities themselves and verification is provided by the service buyers; this may also provide a viable model for PES schemes such as this one in Tanzania (Danielsen et al., 2011; Gross-Camp et al., 2011). The present monitoring data are insufficient to measure the impact of interventions on hydrology, sediment run-off, land-use change, forest integrity, agricultural yields, or livelihoods. This is a significant weakness but is also typical of similar projects elsewhere (Pattanayak et al., 2010). The Uluguru PES project is addressing this issue by purchasing and installing hydrological monitoring equipment and engaging the Water Basin Authority to assist with that effort, and training local farmers to read and interpret the results and start to use them for local decision-making.

Because the project is in a small part of a much larger landscape it is also hard for the project to show impact on downstream water users. The scale of the project intervention is so small compared with the overall Ruvu River Basin that impacts cannot really be expected. Significant scaling up will be required if measurable changes in water quality are to be shown. However, the project has been successful in putting working arrangements in place and agreeing the first pilot water payments in eastern Africa. If a third project phase is agreed this may provide the platform for scaling up to a level that delivers impact that can be more easily measured. This would be good news for the emerging market-based approach to conservation.

\section{Acknowledgements}

We thank our respective institutions for providing time to write this article. CARE and WWF were supported by DANIDA and DGIS to establish this pilot PES project. Useful comments were received from Louise Glew at WWF-USA. We thank Professor Panteleo Munishi at 
Sokoine University of Agriculture and Professor Pius Yanda at the University of Dar es Salaam for allowing us to reproduce hydrological data from a consultant report to the CARE/WWF project. We thank Heri Kayeye at Sokoine University for the map of the study area and intervention farms, and we thank Phil Platts and Jonathan Green at Cambridge University for maps of the Eastern Arc and Uluguru Mountains, respectively.

\section{References}

Asquith, N.M., Vargasa, M.T. \& Wunder, S. (2008) Selling two environmental services: in kind payments for bird habitat and watershed protection in Los Negros, Bolivia. Ecological Economics, 65, 675-684.

Balmford, A., Bruner, A., Cooper, P., Costanza, R., Farber, S., Green, R.E. et al. (2002) Economic reasons for conserving wild nature. Science, 297, 950-953.

Branca, G., Lipper, L., Neves, B., Lopa, D. \& Mwanyoka, I. (2009) New Tools for Old Problems: Can Payments for Watershed Services Support Sustainable Agricultural Development in Africa? ESA Working Paper No. 09-10. Food and Agriculture Organization of the UN, Rome, Italy.

Burgess, N.D., Bahane, B., Clairs, T., Danielsen, F., Dalsgaard, S., Funder, M. et al. (2010a) Getting ready for REDD+ in Tanzania: a case study of progress and challenges. Oryx, 44, 339-351.

Burgess, N.D., Butynski, T.M., Cordeiro, N.J., Doggart, N., FJELDSÅ, J., Howell, K. et al. (2007) The biological importance of the Eastern Arc mountains of Tanzania and Kenya. Biological Conservation, 134, 209-231.

Burgess, N.D., Doggart, N. \& Lovett, J.C. (2002) The Uluguru Mountains of eastern Tanzania: the effect of forest loss on biodiversity. Oryx, 36, 140-152.

Burgess, N.D., Thomas, D., Mhagama, S., Lehmberg, T., SPRINGER, J. \& BARNARD, J. (2010b) Integrated conservation and development projects: a positive role for forest conservation in tropical Africa? In A Handbook of Environmental Management (eds J.C. Lovett \& D.G. Ockwell), pp. 30-75. Edward Elgar Publishing Ltd, Cheltenham, UK.

Butchart, S.H.M., Walpole, M., Collen, B., Van Strien, A., Scharlemann, J.P.W., Almond, R.E.A. et al. (2010) Global biodiversity: indicators of recent declines. Science, 328, 1164-1168.

CARE/WWF (2007) Social and Livelihoods Assessment for Villages Around East Usambara and Uluguru Mountains. CARE International, Dar es Salaam, Tanzania.

Clements, T. (2010) Reduced expectations: the political and institutional challenges of REDD+. Oryx, 44, 309-310.

Clements, T., John, A., Nielsen, K., An, D., Tan, S. \& Milner-Gulland, E.J. (2010) Payments for biodiversity conservation in the context of weak institutions: comparison of three programs from Cambodia. Ecological Economics, 69, 1283-1291.

Daily, G.C. (ed.) (1997) Nature's Services: Societal Dependence on Natural Ecosystems. Island Press, Washington, DC, USA.

Danielsen, F., Skutsch, M.D., Burgess, N.D., Jensen, P.M., Andrianandrasana, H., Karky, B. et al. (2011) At the heart of REDD: a role for local people in monitoring forests? Conservation Letters, 4, 158-167.

Dudley, N. \& Stolton, S. (2003) Running Pure: The Importance of Forest Protected Areas to Drinking Water. World Bank/WWF
Alliance for Forest Conservation and Sustainable Use, WWF International, Gland, Switzerland.

EAMCEF (Eastern Arc Mountains Conservation Endowment Fund) (2011) Http://www.easternarc.or.tz [accessed 17 October 2011].

Engel, S., Pagiola, S. \& Wunder, S. (2008) Designing payments for environmental services in theory and practice: an overview of the issues. Ecological Economics, 65, 663-674.

Ferraro, P.J. (2001) Global habitat protection: limitations of development interventions and a role for conservation performance payments. Conservation Biology, 15, 990-1000.

Ferraro, P.J. (2009) Regional review of payments for watershed services: Sub-Saharan Africa. Journal of Sustainable Forestry, 28, 525-550.

Ferraro, P.J. \& Kiss, A. (2002) Direct payments to conserve biodiversity. Science, 298, 1718-1719.

Fisher, B., Kulindwa, K., Mwanyoka, I., Turner, R.K. \& Burgess, N.D. (2010) Common pool resource management and PES: lessons and constraints for water PES in Tanzania. Ecological Economics, 69, 1253-1261.

Fisher, B., Turner, R.K., Balmford, A., Burgess, N.D., Green, R., Kajembe, G. et al. (2011) Measuring, modeling and mapping ecosystem services in the Eastern Arc Mountains of Tanzania. Progress in Physical Geography, 35, 595-611.

Frontier-Tanzania (2005) Uluguru Component Biodiversity Survey 2005 (Volume II): Uluguru South Forest Reserve (eds C. Bracebridge, E. Fanning, K. Howell, P. Rubio \& F. St John). Society for Environmental Exploration, London, UK; University of Dar es Salaam, Dar es Salaam, Tanzania; CARE, Dar es Salaam, Tanzania; Forestry and Beekeeping Division, Ministry of Natural Resources and Tourism, Dar es Salaam, Tanzania.

Gathenya, J.M. (2009) Monitoring the Impact of EPWS Implementation at Mfizigo Catchment, Kibungo, Uluguru Mountains. CARE/WWF project report. CARE International, Dar es Salaam, Tanzania.

Gross-Camp, N.D., Martin, A., McGuire, S., Kebede, B. \& Munyarukaza, J. (2011) PES in an African protected area: exploring issues of legitimacy, fairness, equity and effectiveness. Oryx, 46, 24-33.

Hall, J., Burgess, N.D., Lovett, J., Mbilinyi, B. \& Gereau, R.E. (2009) Conservation implications of deforestation across an elevational gradient in the Eastern Arc Mountains, Tanzania. Biological Conservation, 142, 2510-2521.

Harrison, P.J., Leimona, B. \& Van Noordwijk, M. (2010) Equitable Payments for Watershed Services: Mid Term Review of Tanzania Component. CARE International and WWF, Dar es Salaam, Tanzania.

Hartley, D. \& KaARe, S.C. (2001) Institutional and Livelihoods Appraisal for Sustainable Conservation of Uluguru Mountains. CARE International, Dar es Salaam, Tanzania.

Kulindwa, K. (2005) A Feasibility Study to Design Payment for Environmental Services Mechanism for Pangani River Basin. IUCN East African Regional Office, Nairobi, Kenya.

Kulindwa, K., Msambichaka, L.A., Lokina, R.B., Hepelwa, A.S., Mngodo, R. \& Swai, R. (2006) A Study to Establish Mechanism for Payments for Water Environmental Services for the Rufiji River Basin in Tanzania. Economic Research Bureau, Dar es Salaam, Tanzania.

Leimona, B., Joshi, L. \& Van Noordwijk, M. (2009) Can rewards for environmental services benefit the poor? Lessons from Asia. International Journal of the Commons, 3, 82-107.

Lyamuya, V.E., Noah, L., Kilasara, M., Kirenga, E. \& Burgess, N.D. (1994) Socio-economic and Land-use Factors Affecting the Degradation of the Uluguru Mountain Slopes, 
Morogoro Region, Tanzania. Royal Society for the Protection of Birds, Sandy, UK.

Madoffe, S. \& Munishi, P.K.T. (2005) Forest Condition Assessment in the Eastern Arc Mountain Forests of Tanzania. Forestry and Beekeeping Division, Ministry of Natural Resources and Tourism, Dar es Salaam, Tanzania.

Madoffe, S.S. \& Munishi, P.K.T. (2010) Forest Condition Assessment in the Eastern Arc Mountain Forests of Tanzania. Forestry and Beekeeping Division of the Ministry of Natural Resources and Tourism, Dar es Salaam, Tanzania.

Mbilinyi, B.P. \& Kashaigili, J.J. (2010) Assessment of Forest Area Changes from 2000 to 2007/08 for the Eastern Arc Mountains. Forestry and Beekeeping Division of the Ministry of Natural Resources and Tourism, Dar es Salaam, Tanzania.

Mbilinyi, B.P., Malimbit, R.E., Shemwetta, D.T.K., Songorwa, A., Zahabu, E., Katani, J.Z. \& Kashaigili, J. (2006) A Forest Area Baseline for the Eastern Arc Mountains. Forestry and Beekeeping Division, Ministry of Natural Resources and Tourism, Dar es Salaam, Tanzania.

McShane, T.O. \& Wells, M.P. (eds) (2004) Getting Biodiversity Projects to Work: Towards More Effective Conservation and Development. Columbia University Press, New York, USA.

MEA (Millennium Ecosystem Assessment) (2005) Millennium Ecosystem Assessment. Ecosystems and Human Well-Being. Island Press, Washington, DC, USA.

Milne, S. \& Niesten, E. (2009) Direct payments for biodiversity conservation in developing countries: practical insights for design and implementation. Oryx, 43, 530-541.

Ministry of Finance and Economic Affairs (2008) The Economic Survey 2007. Dar es Salaam, Tanzania.

Mtalo, F. (ed.) (2005) Hydrology of the Eastern Arc Mountains. Ministry of Natural Resources and Tourism, Forestry and Beekeeping Division, Dar es Salaam, Tanzania.

Muñoz-Piña, C., Guevara, A., Torres, J.M. \& Braña, J. (2008) Paying for the hydrological services of Mexico's forests: analysis, negotiations and results. Ecological Economics, $65,725-736$.

Mwanyoka, I.R. (2005) Payment for Water Services as a Mechanism for Watershed Management: The Case of the Sigi Catchment, Tanga, Tanzania. WWF Tanzania Program Office, Dar es Salaam, Tanzania.

Nsenga, J.V. (2009) Soil and Water Conservation in the Kibungu Sub-Catchment. Centre for Sustainable Rural Development, Sokoine University of Agriculture, Morogoro, Tanzania.

Pagiola, S. (2008) Payments for environmental services in Costa Rica. Ecological Economics, 65, 712-724.

Pascual, U., Muradian, R., Rodriguez, L.C. \& Duraiappah, A.K. (2009) Revisiting the Relationship between Equity and Efficiency in Payments for Environmental Services. Ecosystem Services Economics Working Paper Series. Division of Environmental Policy, Implementation Paper No. 1. UN Environment Programme, Nairobi, Kenya.

Pattanayak, S.K., Wunder, S. \& Ferraro, P.J. (2010) Show me the money: do payments supply environmental services in developing countries? Review of Environmental Economics and Policy, 4, $254-274$
Platts, P.J., Lovett, J.C., Pellikka, P.K.E., Burgess, N.D., Swetnam, R.D., Marshall, A.R. et al. (2011) Defining mountain extent: a spatial classification for the Eastern Arc of Kenya and Tanzania. Environmental Conservation, 38, 312-324.

Ricketts, T.H. (2004) Tropical forest fragments enhance pollinator activity in nearby coffee crops. Conservation Biology, $18,1262-1271$.

Sommerville, M., Jones, J.P.G., Rahajaharison, M. \& Milner-Gulland, E.J. (2010) The role of fairness and benefit distribution in community-based payments for environmental services interventions: a case study from Menabe, Madagascar. Ecological Economics, 6, 1262-1271.

Van Noordwijk, M. \& Leimona, B. (2010) Principles for fairness and efficiency in enhancing environmental services in Asia: payments, compensation, or co-investment? Ecology and Society, $15(4), 17$.

Wunder, S. (2005a) Payments for Environmental Services: Some Nuts and Bolts. Centre for International Forestry Research (CIFOR) Infobrief No. 9. CIFOR Jakarta, Indonesia.

Wunder, S. (2005b) Payments for Environmental Services: Some Nuts and Bolts. Centre for International Forestry Research (CIFOR) Occasional Paper, No. 42. CIFOR, Jakarta, Indonesia.

Wunder, S. (2007) The efficiency of payments for environmental services in tropical conservation. Conservation Biology, 21, 48-58.

W Under, S. (2008) Payments for environmental services and the poor: concepts and preliminary evidence. Environment and Development Economics, 13, 279-297.

Wunder, S. \& Albán, M. (2008) Decentralized payments for environmental services: the cases of Pimampiro and PROFAFOR in Ecuador. Ecological Economics, 65, 685-698.

Wunder, S., Engel, S. \& Pagiola, S. (2008) Taking stock: a comparative analysis of payments for environmental services programs in developed and developing countries. Ecological Economics, 65, 834-852.

Yand A, P. \& Munishi, P.K.T. (2007) Hydrologic and Land Use/Cover Change Analysis for the Ruvu River (Uluguru) and Sigi River (East Usambara) Watersheds. CARE/WWF, Dar es Salaam, Tanzania.

Young, R. \& Fosbrooke, H. (1960) Smoke in the Hills: Political Tension in the Morogoro District of Tanganyika. Northwestern University Press, Evanston, USA.

\section{Biographical sketches}

This multidisciplinary team comprises a mixture of development specialists, managers of pro-poor PES schemes in Africa and Asia, conservation scientists, community forestry and wildlife management specialists, and an environmental economist and lawyer. The team has broad experience in working in Tanzania, on community development and forest conservation, and has been involved with much of the conservation work undertaken in the Uluguru Mountains over the past 2 decades. Together, this team has been involved in the design, management, external review and analytical assessment that forms the core of this article. 